\title{
Genetic Diversity of phlD from 2,4-Diacetylphloroglucinol-Producing Fluorescent Pseudomonas spp.
}

\author{
Olga V. Mavrodi, Brian B. McSpadden Gardener, Dmitri V. Mavrodi, Robert F. Bonsall, \\ David M. Weller, and Linda S. Thomashow
}

First, third, and fourth authors: Department of Plant Pathology, Washington State University, Pullman 99164; and second, fifth, and sixth authors: U.S. Department of Agriculture, Agricultural Research Service, Root Disease and Biological Control Research Unit, Washington State University, Pullman 99164.

Accepted for publication 5 October 2000.

\begin{abstract}
Mavrodi, O. V., McSpadden Gardener, B. B., Mavrodi, D. V., Bonsall, R. F., Weller, D. M., and Thomashow, L. S. 2001. Genetic diversity of phlD from 2,4-diacetylphloroglucinol-producing fluorescent Pseudomonas spp. Phytopathology 91:35-43.

Fluorescent Pseudomonas spp. that produce 2,4-diacetylphloroglucinol (2,4-DAPG) have biocontrol activity against damping-off, root rot, and wilt diseases caused by soilborne fungal pathogens, and play a key role in the natural suppression of Gaeumannomyces graminis var. tritici, known as take-all decline. Diversity within $p h l D$, an essential gene in the biosynthesis of 2,4-DAPG, was studied by restriction fragment length polymorphism (RFLP) analysis of 123 2,4-DAPG-producing isolates from six states in the United States and six other locations worldwide. Clusters

defined by RFLP analysis of phlD correlated closely with clusters defined previously by BOX-polymerase chain reaction (PCR) genomic fingerprinting, indicating the usefulness of $p h l D$ as a marker of genetic diversity and population structure among 2,4-DAPG producers. Genotypes defined by RFLP analysis of phlD were conserved among isolates from the same site and cropping history. Random amplified polymorphic DNA analyses of genomic DNA revealed a higher degree of polymorphism than RFLP and BOX-PCR analyses. Genotypic diversity in a subset of 30 strains representing all the phlD RFLP groups did not correlate with production in vitro of monoacetylphloroglucinol, 2,4-DAPG, or total phloroglucinol compounds. Twenty-seven of the 30 representative strains lacked pyrrolnitrin and pyoluteorin biosynthetic genes as determined by the use of specific primers and probes.
\end{abstract}

Plant growth-promoting rhizobacteria (PGPR) are rhizobacteria that have the ability to promote the growth of plants following inoculation onto seeds or subterranean plant parts (13). PGPR mediate improved plant growth either directly, by stimulation of the plant $(8,15)$ or indirectly, through biological control of pathogens or induction of host defense mechanisms (20,23,35-37). Fluorescent pseudomonads that produce the polyketide antibiotic 2,4diacetylphloroglucinol (2,4-DAPG) are an important group of PGPR that suppress root and seedling diseases on a variety of crops. Examples include Pseudomonas fluorescens CHA0 that suppresses black root rot of tobacco (33), take-all of wheat (10) and Fusarium wilt and crown and root rot of tomato $(6,34)$, Pseudomonas sp. F113 that suppresses damping-off of sugar beet $(7,31)$, and $P$. fluorescens Q2-87 $(9,22)$ and Q8r1-96 (26) that suppress take-all of wheat. Strains of $P$. fluorescens that produce 2,4-DAPG also have a key role in the natural biological control of take-all known as take-all decline (25-27). 2,4-DAPG inhibits a wide range of fungi and bacteria, and its importance in biocontrol activity has been demonstrated conclusively by genetic approaches (35) and direct isolation from the rhizosphere environment $(4,6,25,26)$.

Genes required for the synthesis of 2,4-DAPG by $P$. fluorescens Q2-87 have been cloned (2). The biosynthetic locus includes phlA, $p h l C, p h l B$, and $p h l D$, which are transcribed as an operon from a promoter upstream of phlA (3). PhlD is responsible for the production of monoacetylphloroglucinol (MAPG), and PhlA, PhlC, and PhlB are necessary to convert MAPG to 2,4-DAPG. The biosynthetic operon is flanked on either side by $p h l E$ and $p h l F$, which

Corresponding author: L. S. Thomashow; E-mail address: thomasho@mail.wsu.edu

Publication no. P-2000-1106-02R

This article is in the public domain and not copyrightable. It may be freely reprinted with customary crediting of the source. The American Phytopathological Society, 2001. code respectively for putative efflux and repressor proteins. PhID is especially interesting because of its homology to members of the highly conserved chalcone and stilbene synthase family of plant enzymes, which is suggestive of a common evolutionary origin (3). Probes and primers specific for sequences in phlD have been used in combination with colony hybridization and polymerase chain reaction (PCR) to quantify population sizes of 2,4DAPG producers in the rhizosphere environment $(21,26,27)$.

Several distinct groups of 2,4-DAPG-producing fluorescent pseudomonads have been identified $(11,17,32)$. Two major phenotypic groups have been distinguished based on the production of antifungal compounds, with one group synthesizing 2,4-DAPG, hydrogen cyanide, and pyoluteorin and the other, only the first two metabolites (11). Some pyoluteorin-producing strains such as Pf-5 $(18,19)$ and CHA0 $(10,11,32)$ also can synthesize pyrrolnitrin, although whether this ability is widespread among this group is unclear. Pyoluteorin-producing strains are comparatively homogeneous, whereas pyoluteorin-negative strains include eight distinct genotypes differentiated by random amplified polymorphic DNA (RAPD) analysis. The results of Sharifi-Tehrani et al. (32) suggest that promising biocontrol pseudomonads may be identified functionally, based on the ability to produce 2,4-DAPG, or taxonomically, based on amplified ribosomal DNA restriction analysis (ARDRA) fingerprints. However, ARDRA distinguishes only three $(11,17,32)$ or four $(20)$ groups of $2,4-D A P G$ producers, and does not reflect the full range of diversity among isolates. McSpadden Gardener et al. (17) identified 13 and 15 genotypes by BOX-PCR and enterobacterial repetitive intergeneric consensus (ERIC)-PCR, respectively, in a collection of phlD-containing strains including reference strains from a previous study (11) and isolates from wheat grown in soils from the United States and the Netherlands. In another study, Picard et al. (21) differentiated 64 RAPD genotypes among 150 representatives of a single ARDRA group of phlD-containing isolates from the roots and rhizosphere 
of maize. Such data, which relate population structure to the presence of $p h l D$, reveal a high level of genetic diversity among $p h l D$ containing strains but provide little insight into whether this diversity is paralleled by diversity within phlD itself, or if 2,4-DAPG production and biocontrol efficacy are related to the physical structure of phlD or the 2,4-DAPG biosynthetic operon. Knowledge of the diversity within phlD is a necessary prerequisite to assessing the potential or frequency of horizontal transfer of the biosynthetic genes between members of the rhizosphere microbial community and might provide a basis for developing a rapid genetic screen to identify strains with superior biocontrol activity. The objectives of this research were to define the degree of heterogeneity in phlD among members of a large, genetically diverse collection of 2,4-DAPG-producing fluorescent Pseudomonas spp.; and to determine whether diversity in phlD correlates with whole genome diversity as defined by BOX-PCR and RAPD analyses, or with the amount of 2,4-DAPG produced in vitro. In addition, because 2,4-DAPG producers can be differentiated phenotypically by their ability to produce pyoluteorin and under appropriate culture conditions some also produce pyrrolnitrin, we assessed the frequency of co-occurrence of these biosynthetic genes among the various phlD genotypes.

\section{MATERIALS AND METHODS}

Bacterial strains, growth conditions, and media. A total of $123 \mathrm{phlD}^{+}$strains of fluorescent Pseudomonas spp. isolated from six states in the United States and six other locations worldwide were included in this study (Table 1). The sources and character-

TABLE 1. Bacterial strains used in the study

\begin{tabular}{|c|c|c|c|c|}
\hline $\begin{array}{l}\text { Prefix or } \\
\text { strain }^{w}\end{array}$ & Isolate numbers & RFLP $^{x}$ & Source & Ref. $^{y}$ \\
\hline $\mathrm{CV}$ & $\begin{array}{l}1-1,2-3,2-4,2-8,3-3,3-6,4-1 \\
\quad 4-3,4-5,4-7\end{array}$ & $\mathrm{H}$ & Caldwell, KS & 17 \\
\hline $\mathrm{CC}$ & $1-1,1-3,2-1,2-8,3-6,4-1,5-1$ & $\mathrm{~J}$ & Caldwell, KS & 17 \\
\hline $\mathrm{CC}$ & $3-1$ & $\mathrm{~J} 1$ & Caldwell, KS & 17 \\
\hline FTAD1R & $5,25,26,27,33,34,35,37,38$ & $\mathrm{D}$ & Fargo, ND & $17, \mathrm{TS}$ \\
\hline FTAD1R & 36 & $\mathrm{~J}$ & Fargo, ND & 17 \\
\hline FFL1R & $8,10,13,14,17,18,21,22,25$ & $\mathrm{~J}$ & Fargo, ND & 17 \\
\hline FFL1R & 9 & $\mathrm{D}$ & Fargo, ND & 17 \\
\hline HT & $\begin{array}{l}5-1,5-5,5-8,5-10,5-12,5-15 \\
\quad 6-2,6-4,6-7\end{array}$ & $\mathrm{~N}$ & Hallock, MN & 17 \\
\hline $\mathrm{OC}$ & $4-1,4-2$ & $\mathrm{D}$ & Ithaca, NY & 17 \\
\hline W & $2-4,2-6,2-9$ & $\mathrm{D}$ & Lind, WA & $17, \mathrm{Ts}$ \\
\hline $\mathrm{W}$ & $4-4$ & $\mathrm{~L}$ & Lind, WA & 17 \\
\hline QT & $1-5,5-1,5-2$ & $\mathrm{D}$ & Quincy, WA & 17 \\
\hline QT & $1-6,2-1,2-2,3-1,3-2,4-2,6-1$ & E & Quincy, WA & $17, \mathrm{TS}$ \\
\hline Q & $1-3,1-4,2-1,2-6,2-10,2-12$ & B & Quincy, WA & 17 \\
\hline $\mathrm{Q}$ & $2-5,2-18$ & $\mathrm{D}$ & Quincy, WA & $17, \mathrm{TS}$ \\
\hline Q & $2-2,2-19$ & $\mathrm{E}$ & Quincy, WA & 17 \\
\hline QX-87 & $1,2,4,5,9,12,13,88$ & B & Quincy, WA & 9 \\
\hline QX-87 & 37 & E1 & Quincy, WA & 10 \\
\hline QX-87 & 128 & $\mathrm{D}$ & Quincy, WA & 9 \\
\hline Q8rX-96 & 1 & $\mathrm{D}$ & Quincy, WA & 26 \\
\hline STADX-97 & $\begin{array}{l}375,376,377,378,379,384 \\
\quad 385,387,388389\end{array}$ & $\mathrm{C}$ & Stillwater, OK & TS \\
\hline D27B & $1,2,3,4,5,6,7,8,9,10$ & M & Woensdrecht1 & 17 \\
\hline JMP & $6,7,9,10,11,12,16,17,18,22$ & $\mathrm{~F}$ & Woensdrecht2 & 17 \\
\hline CHA0 & & A & Switzerland & 33 \\
\hline Pf1 & & A & Switzerland & 11 \\
\hline F113 & & $\mathrm{K}$ & Ireland & 31 \\
\hline Pf-5 & & A & Texas & 10,19 \\
\hline PGNR1 & $1,2,3$ & A & Ghana & 11 \\
\hline PINR2 & 2,3 & A & Italy & 11 \\
\hline
\end{tabular}

${ }^{\mathrm{w}} \mathrm{A}$ complete description of the source of each strain is provided in the referenced publications.

${ }^{x}$ Restriction fragment length polymorphism-defined $p h l D^{+}$genotype, based on combined patterns obtained by digestions of 745 bp of phlD with HaeIII, RsaI, and TaqI (Table 3).

y $\mathrm{TS}=$ this study

${ }^{\mathrm{z}}$ To obtain the strain designation, substitute $\mathrm{X}$ with the isolate number. istics of most of the strains were described previously $(11,17)$. Those designated STAD were isolated from the rhizosphere of wheat grown in soil from Stillwater, OK, with a history of continuous cropping to wheat. All strains were cultured on Pseudomonas agar F (Difco Laboratories, Detroit) or King's medium B (KMB) broth (20 g of Bacto proteose peptone, $1.2 \mathrm{~g}$ of $\mathrm{KH}_{2} \mathrm{PO}_{4}$, $1.5 \mathrm{~g}$ of $\mathrm{MgSO}_{4} \cdot 7 \mathrm{H}_{2} \mathrm{O}$, and $10 \mathrm{ml}$ of glycerol per liter) at $25^{\circ} \mathrm{C}$. Stock cultures were stored frozen in Luria-Bertani broth plus $40 \%$ glycerol at $-80^{\circ} \mathrm{C}$.

RAPD analyses. Total genomic DNA was isolated from bacterial strains by a cetyltrimethylammoniumbromide (CTAB)-based miniprep protocol (1) and amplified with the RAPD primer M13 (5'-GGTGGTCAAG-3'). PCR was conducted in a total volume of $25 \mu$ containing $1 \times$ Stoffel fragment buffer, 80 pmol of M13 primer, 0.08 units of Taq polymerase Stoffel fragment (PerkinElmer, Norwalk, CT), $4 \mathrm{mM} \mathrm{MgCl} 2,200 \mu \mathrm{mol}$ each of dATP, dTTP, dGTP, and dCTP (Perkin-Elmer), and $40 \mathrm{ng}$ of genomic DNA. The amplification was performed with a thermocycler (PTC-200; MJ Research, Watertown, MA) and a cycling program that included initial denaturation at $94^{\circ} \mathrm{C}$ for $1.5 \mathrm{~min}$ followed by 2 cycles at $94^{\circ} \mathrm{C}$ for $30 \mathrm{~s}, 36^{\circ} \mathrm{C}$ for $30 \mathrm{~s}$, and $72^{\circ} \mathrm{C}$ for $2 \mathrm{~min}$, and 29 cycles at $94^{\circ} \mathrm{C}$ for $30 \mathrm{~s}, 36^{\circ} \mathrm{C}$ for $15 \mathrm{~s}, 45^{\circ} \mathrm{C}$ for $15 \mathrm{~s}$, and $72^{\circ} \mathrm{C}$ for $1.5 \mathrm{~min}$, and a final extension at $72^{\circ} \mathrm{C}$ for $30 \mathrm{~s}$. All RAPD PCR reactions were run at least twice with similar results. The amplification products were separated on $1.5 \%$ agarose gels in $0.5 \times$ Tris-borate-EDTA (TBE) buffer for $6 \mathrm{~h}$ at $140 \mathrm{~V}$ at $10^{\circ} \mathrm{C}$, stained with ethidium bromide, and photographed under UV light. Images were recorded with a digital imaging system (Kodak DC120; Eastman Kodak Co., Rochester, NY) and analyzed by GelCompar (version 4.0; Applied Maths, Kortrijk, Belgium).

Restriction fragment length polymorphism analyses. Restriction fragment length polymorphism (RFLP)-PCR analyses were performed with whole or heat-lysed cells from 1-day-old cultures grown on Pseudomonas agar F. To lyse cells, two bacterial colonies (2-mm diameter) were suspended in $100 \mu \mathrm{l}$ of lysis solution ( $0.05 \mathrm{M} \mathrm{NaOH}$ and $0.25 \%$ sodium dodecyl sulfate [SDS]) and incubated for $15 \mathrm{~min}$ at $100^{\circ} \mathrm{C}$. The suspension was centrifuged for $1 \mathrm{~min}$ at $12,000 \mathrm{rpm}$ in a microcentrifuge to remove cell debris, diluted 50 -fold in sterile distilled water, and $5 \mu \mathrm{l}$ was used as template for PCR amplification.

The gene-specific primers Phl2a (5'-GAGGACGTCGAAGACCACCA-3') and Phl2b (5'-ACCGCAGCATCGTGTATGAG-3') (27) were used to amplify a 745-bp fragment of phlD. For most strains, the cycling program was as described by Raaijmakers et al. (27). For 25 of 40 strains, including representatives from Caldwell, KS (CV and CC), Hallock, MN (HT), Ithaca, NY (OC), Lind, WA (W), and Quincy, WA (QT), a modified cycling program consisting of initial denaturation at $94^{\circ} \mathrm{C}$ for $90 \mathrm{~s}$ followed by 35 cycles at $94^{\circ} \mathrm{C}$ for $35 \mathrm{~s}, 53^{\circ} \mathrm{C}$ for $30 \mathrm{~s}$, and $72^{\circ} \mathrm{C}$ for $45 \mathrm{~s}$ was used to eliminate additional fragments resulting from nonspecific amplification. The cycling program was followed by final extension at $72^{\circ} \mathrm{C}$ for $30 \mathrm{~s}$. For the remaining 15 strains from Caldwell (CC and CV), the 745-bp phlD fragment was isolated from $0.8 \%$ agarose gels and re-amplified prior to RFLP analysis.

For all strains, amplification products were precipitated with ethanol, resuspended in sterile distilled water, and the DNA concentration was measured spectrophotometrically at $260 \mathrm{~nm}$ (30). Equal volumes $(6 \mu \mathrm{l})$ of the PCR products were digested (30) with HaeIII or RsaI at $37^{\circ} \mathrm{C}$ or $\mathrm{TaqI}$ at $65^{\circ} \mathrm{C}$ for $1.5 \mathrm{~h}$ and stored at $-20^{\circ} \mathrm{C}$. Banding patterns were resolved by electrophoresis in $3.5 \%$ agarose gels (MetaPhor; FMC BioProducts, Rockland, ME) at room temperature in $1 \times \mathrm{TBE}$ buffer for $3 \mathrm{~h}$ at $98 \mathrm{~V}$. Bands were visualized with ethidium bromide and photographed under UV light. Images were recorded and analyzed as described above. PCR reactions were conducted at least twice, with similar results, for a subset of 38 strains containing all of the distinct genotypes found in different soils (as defined by RAPD analyses, described below), and only once for the rest of the strains. 
Banding pattern analysis. The digitized images of RFLP and RAPD bands were converted, normalized, analyzed, and combined with GelCompar version 4.0 software by correlation-based clustering $(28,29)$. A 20-bp molecular ruler (Bio-Rad Laboratories, Hercules, CA) was included in every fifteenth lane in order to normalize the banding pattern of RFLP profiles. Banding patterns of RAPD profiles were normalized with a mixture of 1- and 0.1-kb DNA ladders (New England Biolabs, Beverly, MA). The minimum similarity coefficient of the replicate RAPD PCR assays of all 123 individual strains was used to define distinct clusters of banding patterns. Based on this analysis, 38 representative strains from distinct clusters were chosen for RFLP analysis, which was conducted at least twice. Clusters of the RFLP patterns for the 38 strains were defined by the 95th percentile (near-minimum) similarity coefficient of replicate assays (17) and applied to the complete set of 123 strains, which was analyzed once.

TABLE 2. Oligonucleotide primers used in the study

\begin{tabular}{|c|c|c|c|c|c|}
\hline Primer & Sequence & Target $^{\mathrm{x}}$ & GenBank Accession No. & Position $^{y}$ & $T_{m}{ }^{\mathrm{z}}$ \\
\hline PltBf & CGG AGC ATG GAC CCC CAG C & PltB & AF081920 & $8160-8178$ & $64.0^{\circ} \mathrm{C}$ \\
\hline $\mathrm{PltBr}$ & GTG CCC GAT ATT GGT CTT GAC CGA G & PltB & AF081920 & 8927-8951 (complement) & $63.8^{\circ} \mathrm{C}$ \\
\hline plt1 & ACT AAA CAC CCA GTC GAA GG & PltB & AF081920 & $4812-4831$ & $50.2^{\circ} \mathrm{C}$ \\
\hline PrnCf & CCA CAA GCC CGG CCA GGA GC & $\operatorname{prnC}$ & U74493 & $3478-3497$ & $66.9^{\circ} \mathrm{C}$ \\
\hline $\mathrm{PrnCr}$ & GAG AAG AGC GGG TCG ATG AAG CC & $\operatorname{prnC}$ & U74493 & 4175-4197 (complement) & $62.9^{\circ} \mathrm{C}$ \\
\hline
\end{tabular}

${ }^{x}$ pltB encodes a protein similar to type I polyketide synthase in Pseudomonas fluorescens Pf-5 (18). prnC encodes a halogenase catalyzing chlorination of monodechloroaminopyrrolnitrin to aminopyrrolnitrin in P. fluorescens BL915 (12).

y Position of the primer in the database sequence.

${ }^{\mathrm{z}} T_{m}$, melting temperature calculated by Omiga 2.0.

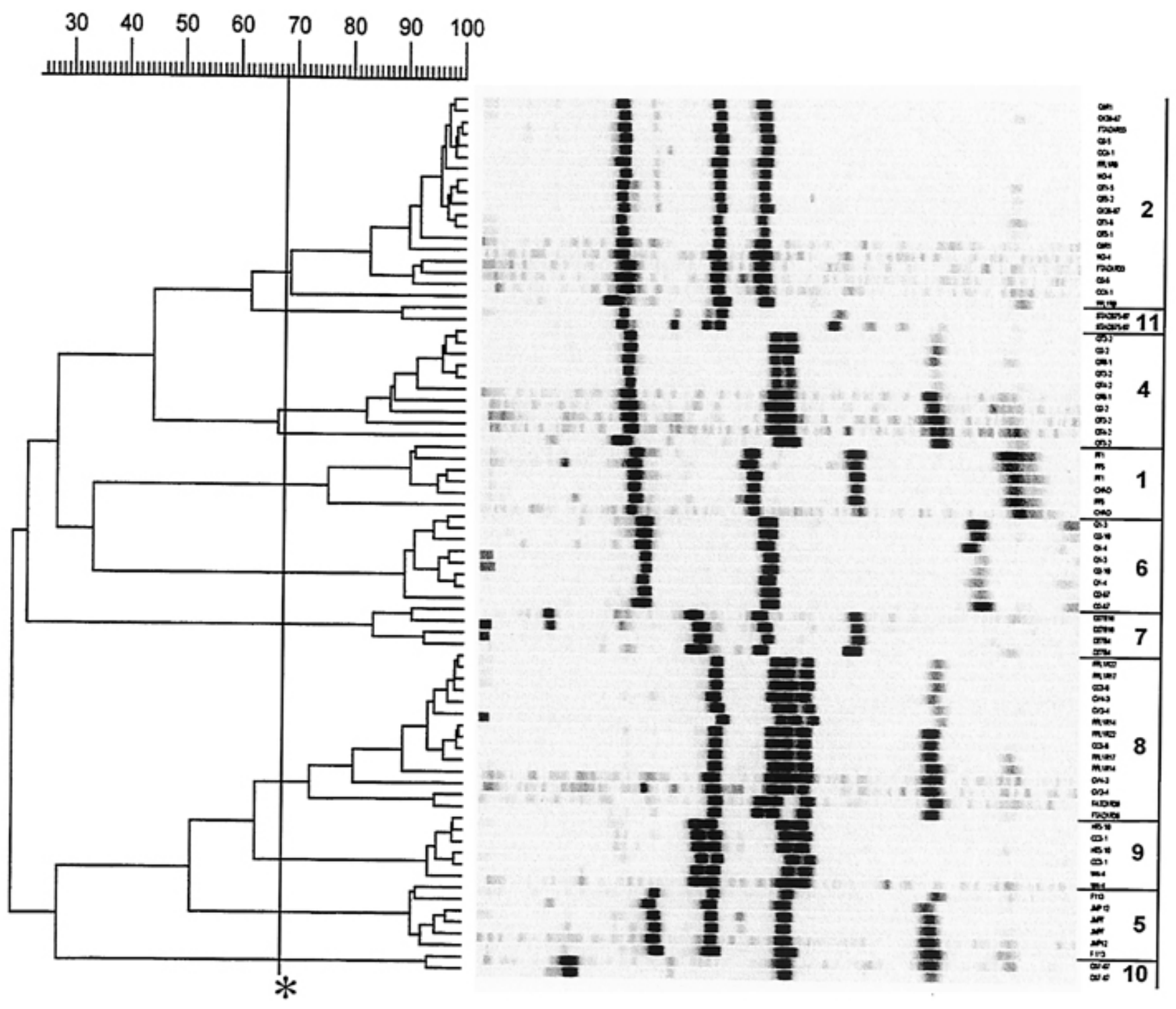

Fig. 1. Random amplified polymorphic DNA cluster analysis of fingerprint patterns generated with the M13 primer from genomic DNA of phlD-containing Pseudomonas spp. strains. Genomic fingerprints patterns for 38 isolates representing all of the unique genotypes present in the collection of 123 isolates are shown. Two independent amplifications were used for each strain. Using GelCompar 4.0, the unweighted pair-group method, arithmetic mean (UPGMA) algorithm was applied to the similarity matrix generated by Pearson's correlation coefficient from the tracks of the whole patterns. The similarity coefficient used to define distinct genotypic groups is noted $(*)$. Strain designations are listed and distinct clusters of the genomic fingerprints are labeled alphabetically. 
Screening for pyoluteorin and pyrrolnitrin biosynthetic loci. The oligonucleotide primers listed in Table 2 were developed by Omiga 2.0 Software (Oxford Molecular Ltd., Oxford, U.K.). Primers PltBf2 and PltBr for the pyoluteorin (Plt) biosynthetic locus were developed from sequences within the module II ketoacyl synthase domain of pltB (GenBank Accession No. AF003370), which encodes a protein in $P$. fluorescens Pf-5 similar to type I polyketide synthases (18). Primers PrnCf and $\mathrm{PrnCr}$ for the pyrrolnitrin (Prn) biosynthetic locus were developed from sequences within prnC (GenBank Accession No. U74493) of $P$. fluorescens BL915, which encodes a halogenase that catalyzes chlorination of monodechloroaminopyrrolnitrin to aminopyrrolnitrin (12). PCR amplification was carried out in $25-\mu$ l reaction mixture containing $1 \times$ Taq DNA polymerase buffer, $200 \mu \mathrm{M}$ each of dATP, dTTP, dGTP, and dCTP, 20 pmol of each primer, $1.5 \mathrm{mM}$ $\mathrm{MgCl}_{2}$, and 0.06 units of AmpliTaq DNA polymerase (PerkinElmer). The PCR cycling program consisted of initial denaturation at $94^{\circ} \mathrm{C}$ for $2 \mathrm{~min}$ followed by 29 cycles of $94^{\circ} \mathrm{C}$ for $1 \mathrm{~min}, 58^{\circ} \mathrm{C}$ for $45 \mathrm{~s}$, and $72^{\circ} \mathrm{C}$ for $1 \mathrm{~min}$. The amplification products were

TABLE 3. Comparison of the genotypic diversity of phlD-containing Pseudomonas spp. defined by restriction fragment length polymorphism (RFLP) analysis of $p h l D$ and genomic fingerprints

\begin{tabular}{|c|c|c|c|c|c|c|}
\hline \multirow[b]{2}{*}{ Strains $^{x}$} & \multicolumn{3}{|c|}{ RFLP genotype $^{y}$} & \multicolumn{3}{|c|}{ Genotype $^{z}$} \\
\hline & $R s a \mathrm{I}$ & $T a q \mathrm{I}$ & HaeIII & Combined & RAPD M13 & BOX-PCR \\
\hline Pf1 & 1 & 1 & 1 & A & A & A \\
\hline Pf-5 & 1 & 1 & 1 & A & A & A \\
\hline CHA0 & 1 & 1 & 1 & A & A & A \\
\hline Q1-3 & 2 & 6 & 6 & B & B & B \\
\hline Q2-10 & 2 & 6 & 6 & B & B & B \\
\hline Q1-4 & 2 & 6 & 6 & B & B1 & B \\
\hline Q2-87 & 2 & 6 & 6 & B & B2 & B \\
\hline STAD375-97 & 2 & 2 & 11 & $\mathrm{C}$ & $\mathrm{C}$ & $C^{*}$ \\
\hline Q8R1-96 & 2 & 2 & 2 & $\mathrm{D}$ & D & D \\
\hline Q128-87 & 2 & 2 & 2 & $\mathrm{D}$ & $\mathrm{D}$ & $\mathrm{D}$ \\
\hline W2-4 & 2 & 2 & 2 & $\mathrm{D}$ & $\mathrm{D}$ & $\mathrm{D}$ \\
\hline QT1-5 & 2 & 2 & 2 & $\mathrm{D}$ & $\mathrm{D}$ & $\mathrm{D}$ \\
\hline QT5-2 & 2 & 2 & 2 & $\mathrm{D}$ & $\mathrm{D}$ & $\mathrm{D}$ \\
\hline FTAD1R33 & 2 & 2 & 2 & $\mathrm{D}$ & D1 & D \\
\hline Q2-5 & 2 & 2 & 2 & $\mathrm{D}$ & D1 & $\mathrm{D}$ \\
\hline OC4-1 & 2 & 2 & 2 & $\mathrm{D}$ & D2 & $\mathrm{D}$ \\
\hline FFL1R9 & 2 & 2 & 2 & $\mathrm{D}$ & D3 & $\mathrm{D}$ \\
\hline Q37-87 & 2 & 4 & 10 & E1 & E & E \\
\hline QT3-2 & 2 & 4 & 4 & E & E & $\mathrm{E}$ \\
\hline QT2-2 & 2 & 4 & 4 & E & E & nd \\
\hline Q2-2 & 2 & 4 & 4 & E & E1 & E \\
\hline QT6-1 & 2 & 4 & 4 & E & E2 & $\mathrm{E}$ \\
\hline QT4-2 & 2 & 4 & 4 & E & E3 & E \\
\hline JMP7 & 2 & 5 & 5 & $\mathrm{~F}$ & $\mathrm{~F} 1$ & $\mathrm{~F}$ \\
\hline JMP12 & 2 & 5 & 5 & F & F & $\mathrm{F}$ \\
\hline CV2-4 & 2 & 4 & 8 & $\mathrm{H}$ & $\mathrm{H}$ & $\mathrm{H}$ \\
\hline CV4-3 & 2 & 4 & 8 & $\mathrm{H}$ & $\mathrm{H}$ & $\mathrm{H}$ \\
\hline FTAD1R36 & 2 & 2 & 8 & $\mathrm{~J}$ & I & I \\
\hline CC3-1 & 2 & 2 & 9 & $\mathrm{~J} 1$ & $\mathrm{~J} 1$ & $\mathrm{~J}$ \\
\hline FFL1R22 & 2 & 2 & 8 & $\mathrm{~J}$ & $\mathrm{~J} 2$ & $\mathrm{~J}$ \\
\hline FFL1R17 & 2 & 2 & 8 & $\mathrm{~J}$ & $\mathrm{~J} 3$ & $\mathrm{~J}$ \\
\hline FFL1R14 & 2 & 2 & 8 & $\mathrm{~J}$ & $\mathrm{~J}$ & $\mathrm{~J}$ \\
\hline CC3-6 & 2 & 2 & 8 & $\mathrm{~J}$ & $\mathrm{~J} 4$ & $\mathrm{~J}$ \\
\hline F113 & 2 & 2 & 5 & $\mathrm{~K}$ & $\mathrm{~K}$ & $\mathrm{~K}$ \\
\hline W4-4 & 3 & 3 & 9 & $\mathrm{~L}$ & D3 & $\mathrm{L}$ \\
\hline D27B4 & 2 & 2 & 7 & M & M & M \\
\hline D27B10 & 2 & 2 & 7 & M & M & M \\
\hline HT5-10 & 2 & 5 & 9 & $\mathrm{~N}$ & $\mathrm{~N}$ & $\mathrm{~N}$ \\
\hline $\mathrm{N}$ & 3 & 6 & 10 & 14 & 25 & 13 \\
\hline
\end{tabular}

${ }^{\mathrm{x}}$ Typical representatives from all unique genotypes. $\mathrm{N}$ indicates total number of distinct genomic groups.

${ }^{y}$ Genotypes were defined using RFLP patterns of $p h l D$ gene generated with restrictions enzymes RsaI, TaqI, and HaeIII.

${ }^{\mathrm{z}}$ Combined $=$ combined patterns obtained with the three restriction enzymes. RAPD $=$ random amplified polymorphic DNA. Genotypes were defined by banding patterns amplified with M13 primer. BOX-PCR = BOX-polymerase chain reaction, result from McSpadden Gardener et al. (17). Asterisk indicates unpublished data and $\mathrm{nd}=$ not determined. electrophoresed in $0.8 \%$ agarose gels in $1 \times \mathrm{TBE}$ buffer for $1 \mathrm{~h}$ at $100 \mathrm{~V}$ at room temperature, stained with ethidium bromide, and photographed under UV light.

For Southern blotting and hybridization, total DNA samples were digested with EcoRI and PstI restriction endonucleases, separated by electrophoresis in a $0.8 \%$ agarose gel, and transferred onto nylon membrane (BrightStar-Plus; Ambion Inc., Austin, TX) in $0.4 \mathrm{M} \mathrm{NaOH}$ with subsequent crosslinking of DNA by exposure of membranes to UV (254 nm) (1). Membranes were prehybridized for $2 \mathrm{~h}$ at 55 to $60^{\circ} \mathrm{C}$ in a solution containing $4 \times \mathrm{SSC}(1 \times$ $\mathrm{SSC}$ is $150 \mathrm{mM} \mathrm{NaCl}$ plus $15 \mathrm{mM}$ sodium citrate, $\mathrm{pH}$ 7.0) (30), $4 \times$ Denhardt's solution (30), 0.1\% SDS, and $100 \mu \mathrm{g}$ of denatured salmon sperm DNA (Sigma Chemical Co., St. Louis) per ml. Prehybridized membranes were incubated with probes overnight under the same conditions and washed with $2 \times$ SSC, $0.1 \%$ SDS at room temperature (twice), $0.2 \times \mathrm{SSC}, 0.1 \% \mathrm{SDS}$ at room temperature (twice), $0.2 \times \mathrm{SSC}, 0.1 \% \mathrm{SDS}$ at 55 to $60^{\circ} \mathrm{C}$ (twice), and $0.1 \times \mathrm{SSC}, 0.1 \% \mathrm{SDS}$ at 55 to $60^{\circ} \mathrm{C}$ (once). DNA-DNA hybrids were detected with a nonisotopic detection kit (BrightStar; Ambion) according to the manufacturer's protocol. The plt and prn gene probes were amplified from genomic DNA of $P$. fluorescens Pf-5 with the primer pairs Plt1 and Plt2 (which anneal to the 5' end and internally to $p l t B$ ) or PrnCf and PrnCr (Table 2), respectively, and labeled with a random primer biotin labeling kit (NEN Life Science Products, Boston, MA).

Extraction and detection of 2,4-DAPG and related metabolites. Strains were grown in $\mathrm{KMB}$ broth for $72 \mathrm{~h}$ at $25^{\circ} \mathrm{C}$. Samples $(400 \mu \mathrm{l})$ were acidified with $4.5 \mu \mathrm{l}$ of $10 \%$ trifluoroacetic acid (TFA) and extracted twice with $1 \mathrm{ml}$ of ethyl acetate $(90 \%$ extraction efficiency). The organic phase containing phloroglucinol derivatives was evaporated to dryness and suspended in $100 \mu \mathrm{l}$ of $35 \%$ acetonitrile (ACN) containing 1\% TFA. Thirty-microliter volumes of the extracts, or dilutions thereof, were fractionated by $\mathrm{C}_{18}$ reverse phase high-performance chromatography (HPLC) on a Waters NOVA-PAK $\mathrm{C}_{18}$ Radial-PAK cartridge $(4 \mu \mathrm{m}, 8 \times 100 \mathrm{~mm}$, Waters Corp., Milford, MA) (4). Solvent conditions included a flow rate of $1.0 \mathrm{ml} / \mathrm{min}$ with a 2 -min initial condition at $10 \%$ ACN-0.1\% TFA, followed by a 20 -min linear gradient to $100 \%$ ACN-0.1\% TFA. HPLC gradient profiles were monitored at the spectral peak maxima (270 and $330 \mathrm{~nm}$ ) characteristic of phloroglucinol compounds in the designated solvent system. The HPLC system included a 710B WISP, 510 pumps, and a 680 automated gradient controller with 990 photodiode array detector. 2,4-DAPG and MAPG were identified by retention time and ultraviolet spectra (4). Each strain was grown and assayed three separate times.

Statistics. The statistics related to the genotypic diversity (i.e., Pearson's correlation coefficient, unweighted pair-group method, arithmetic mean [UPGMA] clustering) were calculated with GelCompar 4.0. When analyzing the HPLC data, all statistics were calculated using the JMP software release 3.2 (SAS Institute, Cary, NC). The peak areas corresponding to each of the phloroglucinol compounds were compared using the Tukey-Kramer test. Additionally, the correlation between MAPG and 2,4-DAPG production was calculated by Kendall's tau.

\section{RESULTS}

RAPD analysis of $\mathbf{p h l D}^{+}$strains. Based upon the presence or absence of amplification products ranging in size from 200 to 3,500 bp, 25 different M13 RAPD patterns (Fig. 1) were distinguished among the $123 \mathrm{phlD}^{+}$isolates tested. Isolates from Quincy, Lind, Fargo (ND), and Ithaca, previously described by McSpadden Gardener et al. (17) as BOX group D, were separated into four RAPD groups designated D (Q8r1-96 and W2-4), D1 (FTAD1R33, Q2-5), D2 (OC4-1), and D3 (FFL1R9) (Table 3). Similarly, BOX groups B, E, F, and J formed three, four, two, and five additional subgroups, respectively (Table 3). Eighty-four percent of the distinct RAPD groups defined in this collection con- 
tained isolates from single geographic locations. However, groups A, D, D1, and D3 included isolates from more than one location. Multiple RAPD genotypes were detected among isolates obtained from Caldwell, Fargo, Lind, and Quincy. For example, FTAD1R isolates from long-term wheat soil at Fargo included members of RAPD groups D1 and I. FFL1R isolates from long-term flax soil were distributed among RAPD groups D3, J, J2, and J3. Single genotypes occurred among HT, OC, STAD, and D27B isolates from Hallock, Ithaca, Stillwater, and Woensdrecht1, respectively. Comparison of the RAPD and BOX-PCR clustering patterns indicated seven identical groups (A, C, H, I, K, M, and N), with the remaining six BOX groups separated into 18 groups by RAPD analysis (Table 3 ).

RFLP analyses of $\boldsymbol{p h l D}$. The results of the RFLP analyses are summarized in Table 3 for a set of 38 phlD strains that includes representatives of each of the 25 distinct groups identified by RAPD analysis. Digestion with RsaI and TaqI identified only three and six groups, respectively, whereas digestion with HaeIII distinguished 10 groups of phlD strains. Group one was distinct by all three digests. Group two, as defined by RFLP-RsaI analy- sis, was separated into four groups by TaqI analysis and into eight groups by RFLP-HaeIII analysis. Figure 2 shows the RFLP for the 38 strains listed in Table 3, digested with HaeIII restriction endonuclease. The combined patterns obtained with the three restriction endonucleases defined 14 distinct genomic groups among the reduced set of 38 representative strains (Table 3) and the full set of 123 different isolates (Table 1). Among the 14 groups, only groups $\mathrm{A}, \mathrm{D}$, and $\mathrm{J}$ included isolates from more than one location. Of these, the D group was the largest and contained 22 isolates (18\% of the total) from Quincy, Lind, Ithaca, and Fargo. The second largest group, J, included 17 isolates (14\% of the total) from two different soils, one from Caldwell and the other from Fargo. Group A contained strains CHA0, Pf1, Pf-5, PINR2, PINR3, PGNR1, PGNR2, and PGNR3, isolated from Swiss, Italian, Texas, and Ghanian soils (11). All of these strains were reported to produce 2,4-DAPG and pyoluteorin (11). The other 11 genotypes each contained isolates from a single location. The JMP and D27B isolates, from two different fields in the Netherlands, clustered in groups $\mathrm{F}$ and $\mathrm{M}$, respectively. Group B contained isolates from Quincy, with the QX-87 isolates obtained from a

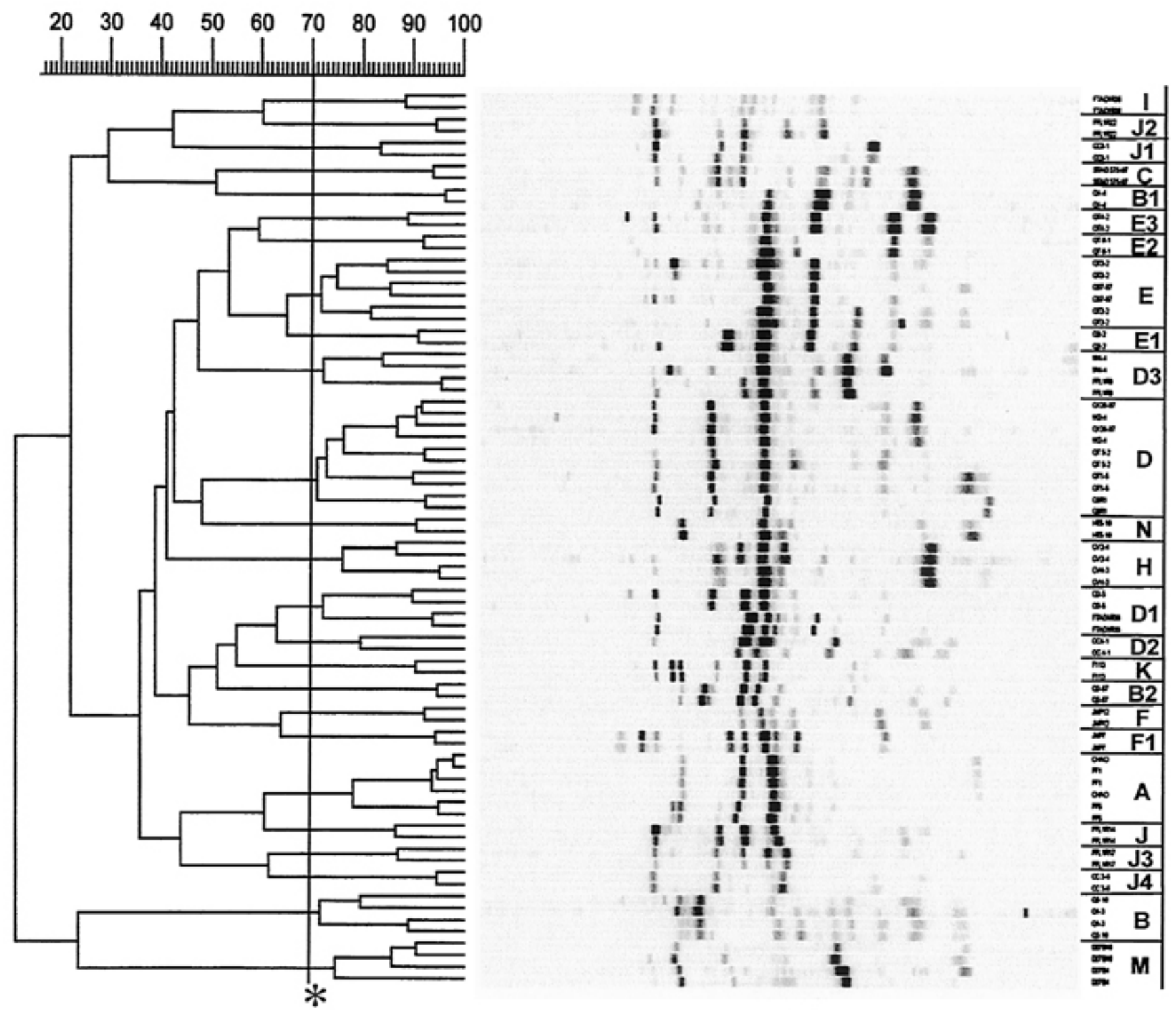

Fig. 2. Cluster analysis of restricted fragment length polymorphism (RFLP) patterns obtained from the digestion of the 745-bp phlD fragment with HaeIII. Patterns for 38 isolates representing all of the unique random amplified polymorphic DNA-defined genotypes are shown. Two independent amplifications were used for each strain. Using GelCompar 4.0, the unweighted pair-group method, arithmetic mean algorithm was applied to the similarity matrix generated from the tracks of the whole patterns by Pearson's correlation coefficient. The similarity coefficient used to define distinct groups is noted $(*)$. Strain designations are listed, and distinct clusters of RFLP patterns are labeled numerically. 
growth chamber experiment in 1987 and the Q isolates isolated from the field in 1998. Clusters E1, K, and L each contained a single representative: Q37-87 from Quincy, F113 from Ireland, and W4-4 from Lind, respectively.

Interestingly, the genomic groups identified by the combined RFLP analysis were nearly identical to the groups defined by BOX-PCR analysis. In the reduced set, 35 of the 38 strains (92\%) clustered in the same genotypic groups by both methods. The only exceptions were strains Q37-87 and CC3-1, which were separated by RFLP analysis into groups E1 and J1, respectively. A comparison of the RFLP and RAPD fingerprinting techniques showed seven identical groups (A, C, H, J1, K, M, and N), with the remaining seven RFLP groups separated by RAPD into 18 groups (Table 3).

Production of phloroglucinol compounds in vitro. Thirty strains representative of 13 RFLP genotypes were analyzed by HPLC for phloroglucinol production in KMB broth, which supported the synthesis of larger amounts of 2,4-DAPG by a greater number of strains than did yeast malt or Pseudomonas $\mathrm{F}$ broth (data not shown). Among the 30 strains, 24 produced detectable amounts of 2,4-DAPG as well as MAPG and three other uncharacterized phloroglucinol derivatives (Table 4). All three of the RFLP-defined group A strains tested (CHA0, Pf1, and Pf-5) and three other strains (CC3-6, HT5-10, and W4-4), failed to produce detectable phloroglucinol compounds under these assay conditions. Among the 24 strains where phloroglucinol compounds were detected, production of DAPG and MAPG were positively correlated (Kendall's tau $=0.46 ; P<0.001$ ). Strain CV4-3 produced more MAPG and 2,4-DAPG than the other strains, but in general, the 24 isolates did not produce significantly different amounts of either MAPG or 2,4-DAPG under our assay conditions. Because MAPG is a precursor of 2,4-DAPG (3,31), and the uncharacterized phloroglucinol compounds detected in these analyses are likely to include condensation products of either or both compounds (R. F. Bonsall, O. V. Mavrodi, D. V. Mavrodi, and D. M. Weller, unpublished data), we also assayed total phloroglucinol production. The data indicated that except for RFLP genotypes $\mathrm{H}$ and J, representatives within an RFLP genotype (i.e., A, B, D, E, and M) did not differ in the amounts of phloroglucinol compounds produced (Table 4). Only two strains, CV4-3 (group H) and CC3-1 (group J1) produced significantly more phloroglucinol-containing compounds than most of the other strains tested (Table 4).

Screening of phlD Pseudomonas spp. for pyoluteorin and pyrrolnitrin biosynthetic loci. Thirty strains representative of 13 phlD RFLP groups were screened for the presence of pyoluteorin and pyrrolnitrin biosynthetic loci by PCR with the PltBf2 and $\mathrm{PltBr}$ or PrnCf and PrnCr primers, respectively (Table 2). Primers PltBf 2 and PltBr amplified the predicted 773-bp fragment of pltB from the DNA of $P$. fluorescens strains CHA0, Pf-5, and Pf1. All of these strains are members of RFLP genotype A. No PCR product was amplified from any of the other phlD strains (data not shown). Similar results were obtained with the $\mathrm{PrnCf}$ and $\mathrm{PrnCr}$ primers that amplified the predicted 719-bp fragment of prnC from the same three strains (CHA0, Pf-5, and Pf1) but not from the other 27 strains (data not shown). Southern hybridization of digested total genomic DNA from the same 30 strains with plt and prn gene probes yielded results identical to those obtained by PCR screening (Fig. 3). Under stringent conditions the plt and prn probes hybridized only with genomic DNA obtained from $P$. fluorescens strains $\mathrm{CHA} 0, \mathrm{Pf} 5$, and Pf1 (Fig. 3).

\section{DISCUSSION}

Antibiotic-producing PGPR have been studied intensively during the last decade, and special attention has been given to 2,4-

TABLE 4. Production of phloroglucinol compounds by fluorescent Pseudomonas spp. in King's medium B broth ${ }^{\mathrm{z}}$

\begin{tabular}{|c|c|c|c|c|c|}
\hline Strain & Genotype & MAPG & DAPG & $\mathrm{MAPG}+2,4-\mathrm{DAPG}$ & PHL compounds \\
\hline CHAO & A & ND & ND & ND & ND \\
\hline PF1 & A & ND & ND & ND & ND \\
\hline Pf-5 & A & ND & ND & $\mathrm{ND}$ & ND \\
\hline Q1-3 & $\mathrm{B}$ & $0.17(0.05) \mathrm{a}-\mathrm{c}$ & $0.11(0.13) \mathrm{a}$ & $0.23(0.13) \mathrm{ab}$ & $0.57(0.15) \mathrm{ab}$ \\
\hline Q1-4 & B & $0.16(0.05) \mathrm{a}-\mathrm{c}$ & $0.18(0.13) a b$ & $0.34(0.13) \mathrm{ab}$ & $0.78(0.15) \mathrm{ab}$ \\
\hline Q2-87 & B & $0.09(0.05) \mathrm{ab}$ & $0.08(0.13) \mathrm{a}$ & $0.17(0.13) \mathrm{ab}$ & $0.32(0.15) \mathrm{a}$ \\
\hline STAD375-97 & $\mathrm{C}$ & $0.10(0.05) \mathrm{ab}$ & $0.11(0.13) \mathrm{a}$ & $0.21(0.13) \mathrm{ab}$ & $0.51(0.15) \mathrm{ab}$ \\
\hline Q8R1-96 & $\mathrm{D}$ & $0.16(0.05) \mathrm{ab}$ & $0.10(0.13) \mathrm{a}$ & $0.26(0.13) \mathrm{ab}$ & $0.67(0.15) \mathrm{ab}$ \\
\hline Q128-87 & $\mathrm{D}$ & $0.11(0.05) \mathrm{ab}$ & $0.07(0.13) \mathrm{a}$ & $0.18(0.13) a b$ & $0.53(0.15) \mathrm{ab}$ \\
\hline W2-4 & $\mathrm{D}$ & $0.16(0.05) \mathrm{a}-\mathrm{c}$ & $0.05(0.13) \mathrm{a}$ & $0.21(0.13) \mathrm{ab}$ & $0.75(0.15) \mathrm{ab}$ \\
\hline QT5-2 & $\mathrm{D}$ & $0.17(0.05) \mathrm{a}-\mathrm{c}$ & $0.41(0.13) \mathrm{a}-\mathrm{c}$ & $0.57(0.13) a b c$ & $0.98(0.15) \mathrm{ab}$ \\
\hline FTAD1R33 & $\mathrm{D}$ & $0.17(0.05) \mathrm{a}-\mathrm{c}$ & $0.07(0.13) \mathrm{a}$ & $0.23(0.13) a b$ & $0.71(0.15) a b$ \\
\hline OC4-1 & $\mathrm{D}$ & $0.18(0.05) \mathrm{abc}$ & $0.08(0.13) \mathrm{a}$ & $0.26(0.13) \mathrm{ab}$ & $0.78(0.15) \mathrm{ab}$ \\
\hline Q37-87 & E1 & $0.33(0.05) \mathrm{abc}$ & $0.15(0.13) \mathrm{ab}$ & $0.48(0.13) \mathrm{a}-\mathrm{c}$ & $0.92(0.15) \mathrm{ab}$ \\
\hline QT2-2 & $\mathrm{E}$ & $0.12(0.05) \mathrm{ab}$ & $0.08(0.13) \mathrm{a}$ & $0.21(0.13) \mathrm{ab}$ & $0.50(0.15) \mathrm{ab}$ \\
\hline Q2-2 & $\mathrm{E}$ & $0.11(0.06) \mathrm{ab}$ & $0.07(0.16) \mathrm{ab}$ & $0.18(0.16) \mathrm{ab}$ & $0.47(0.19) \mathrm{ab}$ \\
\hline JMP12 & $\mathrm{F}$ & $0.44(0.05) \mathrm{b}-\mathrm{d}$ & $0.43(0.13) \mathrm{a}-\mathrm{c}$ & $0.88(0.13) b c$ & $1.33(0.15) b$ \\
\hline CV2-4 & $\mathrm{H}$ & $0.68(0.05) b-d$ & $0.39(0.13) \mathrm{a}-\mathrm{c}$ & $1.07(0.13) b c$ & $1.51(0.15) \mathrm{b}$ \\
\hline CV4-3 & $\mathrm{H}$ & $1.98(0.05) \mathrm{f}$ & $2.16(0.13) \mathrm{d}$ & $4.14(0.13) \mathrm{e}$ & $4.36(0.15) \mathrm{d}$ \\
\hline FFL1R25 & $\mathrm{J}$ & $0.25(0.05) \mathrm{a}-\mathrm{c}$ & $0.03(0.13) \mathrm{a}$ & $0.28(0.13) \mathrm{ab}$ & $0.82(0.15) \mathrm{ab}$ \\
\hline CC3-6 & $\mathrm{J}$ & ND & ND & ND & ND \\
\hline FTAD1R36 & $\mathrm{J}$ & $0.22(0.05) \mathrm{a}-\mathrm{c}$ & $0.04(0.13) \mathrm{a}$ & $0.26(0.13) a b$ & $0.57(0.15) a b$ \\
\hline FFL1R14 & $\mathrm{J}$ & $0.38(0.06) \mathrm{b}-\mathrm{d}$ & $0.34(0.16) \mathrm{a}-\mathrm{c}$ & $0.72(0.16) \mathrm{a}-\mathrm{c}$ & $1.01(0.19) \mathrm{ab}$ \\
\hline FFL1R17 & $\mathrm{J}$ & $0.14(0.05) \mathrm{ab}$ & $0.04(0.13) \mathrm{a}$ & $0.17(0.13) a b$ & $0.85(0.16) a b$ \\
\hline FFL1R22 & $\mathrm{J}$ & $0.06(0.05) \mathrm{a}$ & $0.01(0.13) \mathrm{a}$ & $0.07(0.13) \mathrm{a}$ & $0.51(0.15) \mathrm{ab}$ \\
\hline CC3-1 & $\mathrm{J} 1$ & $1.29(0.05) \mathrm{c}$ & $0.82(0.13) b c$ & $2.11(0.13) \mathrm{d}$ & $2.65(0.15) \mathrm{c}$ \\
\hline W4-4 & $\mathrm{L}$ & ND & ND & ND & ND \\
\hline D27B4 & $\mathrm{M}$ & $0.15(0.06) \mathrm{a}-\mathrm{c}$ & $1.12(0.16) b c$ & $1.3(0.16) b c$ & $1.27(0.19) \mathrm{b}$ \\
\hline D27B 10 & M & $0.25(0.05) \mathrm{a}-\mathrm{c}$ & $0.51(0.13) \mathrm{a}-\mathrm{c}$ & $0.76(0.13) \mathrm{a}-\mathrm{c}$ & $0.76(0.16) \mathrm{ab}$ \\
\hline HT5-10 & $\mathrm{N}$ & ND & ND & ND & ND \\
\hline
\end{tabular}

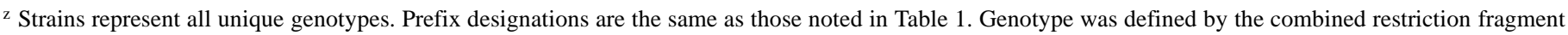
length polymorphism analyses of phlD. All phloroglucinol (PHL) compounds include monoacetylphloroglucinol (MAPG), 2,4-diacetylphloroglucinol (DAPG), and three other uncharacterized PHL derivatives (R. F. Bonsall, O. V. Mavrodi, D. V. Mavrodi, and D. M. Weller, unpublished data). Each value is the mean and standard deviation of the peak area (absorbance units at $270 \mathrm{~nm}$ ) of three replicate assays. ND = not detected. Values followed by the same letter are not significantly different according to the Tukey-Kramer test $(P<0.05)$.
} 
DAPG-producing fluorescent Pseudomonas spp. because of their ability to control a wide variety of plant diseases $(5-7,22,32-$ 34,37). At the same time, the application of molecular techniques has significantly changed our capacity to rapidly characterize PGPR, their mechanisms of pathogen suppression and growth promotion, and to track indigenous and introduced rhizobacteria in the field. For example, probes and primers specific for sequences within phlD have been used to monitor the population dynamics of 2,4-DAPG producers in take-all suppressive and conducive soils $(26,27)$ and in the rhizosphere of maize (21). Studies of the genotypic diversity of 2,4-DAPG producers by different techniques, including BOX-PCR, ERIC-PCR, ARDRA, RAPD, and RFLP analyses, have revealed a substantial number of distinct groups $(11,17,21,32)$. Genomic fingerprinting with repetitive sequence-based (rep)-PCR, which has been used to analyze the diversity of a wide variety of bacterial taxa (14), revealed 13 and 15 distinct groups of phlD isolates by the BOXAIR and ERIC primers, respectively (17). Our present study extended the genotypic analysis of a large collection of 2,4-DAPG producers to include RAPD analysis of the whole genome and RFLP analyses of the phlD gene, which encodes a protein necessary for the biosynthesis of phloroglucinol compounds $(2,3)$. It was not unexpected that the diversity among phlD strains, as detected by RAPD analysis, was consistent with that defined by rep-PCR because both are measures of the overall genomic structure. However, we were surprised to find that the genotypic groups identified by RFLP analysis of phlD correlated nearly perfectly with those identified by BOXPCR (17) (Table 3). These two types of analysis, one focused on the entire genome and the other on a single gene, strongly suggest that the phlD gene evolved in concert with the rest of the bacterial genome. This observation argues against frequent horizontal transfers of the phl locus between strains and should lessen concern about the potential for transfer of the locus to other rhizosphere bacteria when 2,4-DAPG producers are applied as biocontrol agents.

RAPD analysis revealed the highest degree of polymorphism among the strains studied. Five of the groups (B, D, E, F, and J) defined by $p h l D^{+}$RFLP and BOX-PCR were divided into 17

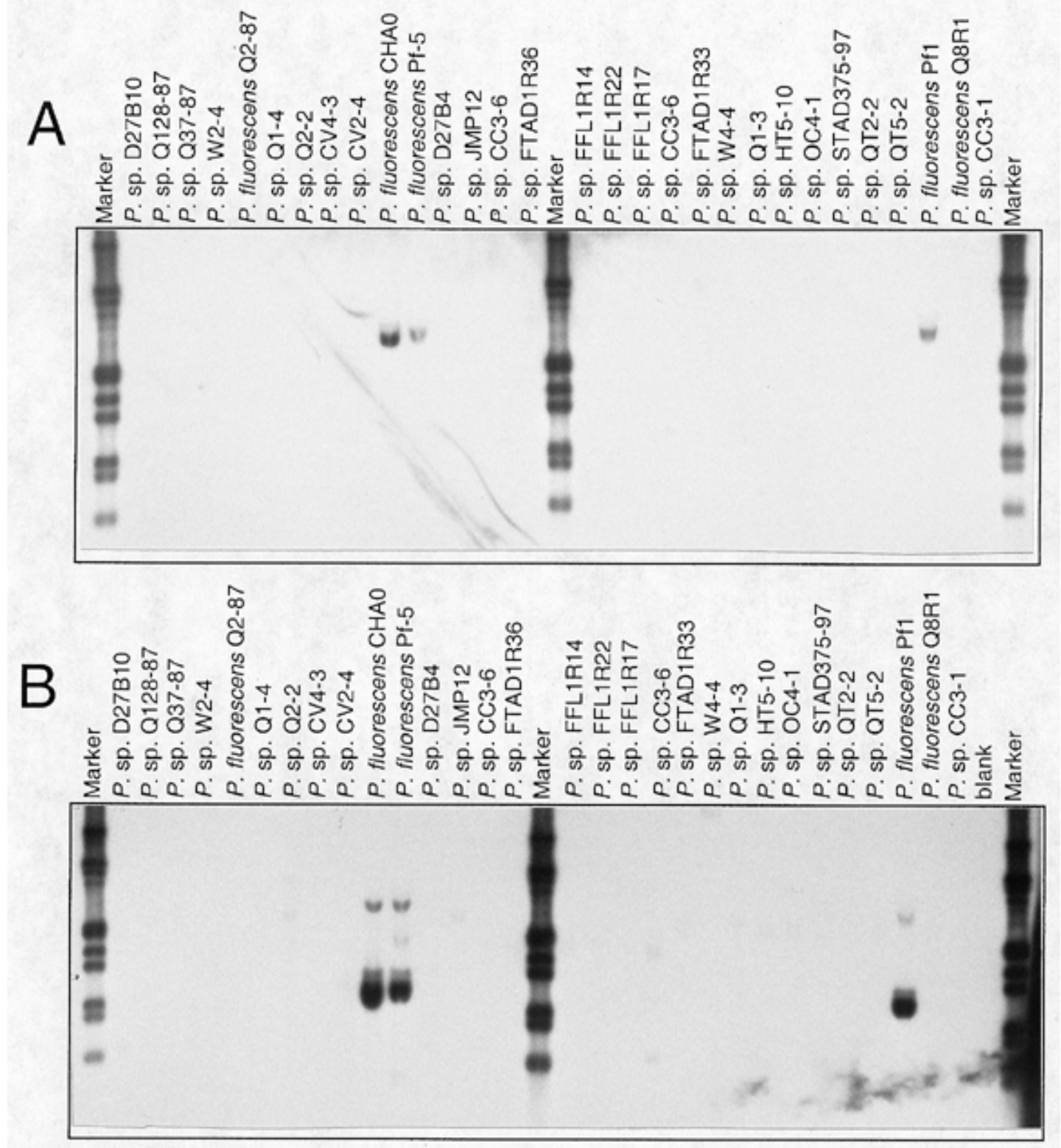

Fig. 3. Southern hybridization of DNA from phlD strains with probes for pyoluteorin and pyrrolnitrin biosynthetic loci. Total genomic DNA from each strain was digested with EcoRI and PstI restriction endonucleases, separated by electrophoresis in a $0.8 \%$ agarose gel, and transferred onto a BrightStar-Plus nylon membrane. The blots were hybridized with biotin-labeled probes targeting A, pltB or B, prnC. The plt and prn probes were prepared, respectively, from the 440-bp polymerase chain reaction (PCR) amplified with Plt1 and Plt2 or the 719-bp PCR product amplified with PrnCf and PrnCr from Pseudomonas fluorescens strain Pf-5. 
groups by RAPD analysis. The larger number of genotypes distinguished by the RAPD assay as compared with the two other assays was somewhat unexpected. However, Pooler et al. (24) observed a similar situation when studying the genetic diversity of 25 isolates of Xanthomonas fragariae by RAPD, ERIC-PCR, and REP-PCR. In that study, RAPD assays also revealed more genotypic diversity than rep-PCR (24). Both methods clearly provide a high degree of discrimination in analyses of population structure, but based on our experience with phlD Pseudomonas spp., we agree with Louws et al. (14) that rep-PCR genomic fingerprinting analyses are more amenable to whole-cell PCR and provide more consistent results than standard RAPD analyses. We anticipate that these genomic fingerprints or the associated phlD RFLP profiles will be useful to predict the relative ability of a 2,4-DAPG producer to suppress certain diseases or to colonize certain host crops. By matching the crop or crop variety with the appropriate $\mathrm{phlD}^{+}$genotype, it may be possible to achieve consistent and effective biological control or growth promotion at lower inoculum doses than currently applied.

Previous studies $(11,32)$ have differentiated 2,4-DAPG-producing Pseudomonas spp. into two groups based on the number of antifungal metabolites produced. The first group, consisting of strains isolated from tobacco, tomato, cucumber, and cotton, produces 2,4-DAPG, hydrogen cyanide, and pyoluteorin. In contrast, members of the second group produce only 2,4-DAPG and hydrogen cyanide. We screened our collection of phlD isolates for the pyoluteorin and pyrrolnitrin biosynthetic genes to determine whether the ability to produce these other metabolites is widely distributed within a diverse spectrum of 2,4-DAPG producers. We used a genetic approach for this purpose, rather than direct analysis of the metabolites themselves, to avoid potential effects of culture conditions on synthesis. We were surprised to find that the distribution of these genes was very limited within our collection of isolates from widely distributed soils and soils with long histories of agricultural cropping. The clear presence of plt and prn genes only with strains belonging to group A, as defined by phlDRFLP, genomic RAPD, BOX-PCR, and ARDRA analyses, may indicate that the co-occurrence of these biosynthetic pathways is limited to this specific group of 2,4-DAPG producers.

Another important goal of our study was to determine the relationship between genotype and 2,4-DAPG production. Our HPLC analyses of metabolites from 30 strains representing 13 distinct phlD-RFLP genotypes demonstrated that except for strains of group A (which consistently did not produce phloroglucinol compounds at detectable levels under the culture conditions used), there was no clear association between phlD-RFLP genotype and 2,4-DAPG production, because most strains produced similar amounts of phloroglucinol compounds regardless of genotype. Notable exceptions included strains CV4-3 and CC3-1, which produced significantly more phloroglucinol compounds than other strains. Keel et al. (11) also did not detect production of phloroglucinol compounds when strains CHA0, Pf1, and Pf-5 were grown on KMB agar. This medium may not be optimal for the production of phloroglucinol compounds or the compounds may be degraded. In either case, we think that the amounts detected in vitro are unlikely to be indicative of the biologically active levels produced in nature. For example, in the case of $P$. fluorescens strain CHA0, 2,4-DAPG was not produced in our in vitro assays but it has been recovered from the rhizosphere of tomato plants inoculated with CHA0 (6). In our laboratories, studies are in progress to determine the relationship between production of 2,4DAPG in situ and the biocontrol activity of different phlD genotypes in the rhizosphere of crop plants (B. McSpadden Gardener and D. M. Weller, unpublished data).

Our results, like those of McSpadden Gardener et al. (17), indicate that in most cases a single phlD genotype predominated among isolates from each soil. Although multiple genotypes were observed among isolates from the Fargo, Quincy, Caldwell, Lind, and Woensdrecht soils, one genotype was still predominant. The presence of multiple genotypes in some soils can be explained, in part, by different isolation techniques for strains obtained from the Quincy site, and by different cropping histories for soils obtained from Fargo and Woensdrecht (17). Because differences in the phlD gene reflect the overall genetic diversity among 2,4-DAPGproducing strains from soils of different geographical origins and cropping histories, we conclude that phlD itself can be used to study the genetic diversity and population structure of such strains. Recently, a rapid PCR-based technique was developed in our laboratory to quantify population sizes of phlD strains in rhizosphere samples (16). With this technique it will be possible to rapidly determine the genotype of the most dominant 2,4-DAPG producers in a sample by PCR-RFLP analyses similar to those described here.

\section{ACKNOWLEDGMENTS}

This research was supported by grant 97-35107-4804 from the U.S. Department of Agriculture, National Research Initiative, Competitive Grants Program.

\section{LITERATURE CITED}

1. Ausubel, F. M., Brent, R., Kingston, R. E., Moore, D. D., Seidman, J. G., Smith, J. A., and Struhl, K. (eds.) 1995. Short Protocols in Molecular Biology. 3rd ed. John Wiley \& Sons, New York.

2. Bangera, M. G., and Thomashow, L. S. 1996. Characterization of a genomic locus required for the synthesis of the antibiotic 2,4-diacetylphloroglucinol by the biological control agent Pseudomonas fluorescens Q2-87. Mol. Plant-Microbe Interact. 9:83-90.

3. Bangera, M. G., and Thomashow, L. S. 1999. Identification and characterization of a gene cluster for synthesis of the polyketide antibiotic 2,4diacetylphloroglucinol from Pseudomonas fluorescens Q2-87. J. Bacteriol. 181:3155-3163.

4. Bonsall, R. F., Weller, D. M., and Thomashow, L. S. 1997. Quantification of 2.4-diacetylphloroglucinol produced by fluorescent Pseudomonas spp. in vitro and in the rhizosphere of wheat. Appl. Environ. Microbiol. 63:951-955.

5. Cook, R. J., Thomashow, L. S., Weller, D. M., Mazzola, M., Bangera, G., and Kim, D.-S. 1995. Molecular mechanisms of defense by rhizobacteria against root disease. Proc. Natl. Acad. Sci. USA 92:4197-4201.

6. Duffy, B. K., and Défago, G. 1997. Zinc improves biocontrol of Fusarium crown and root rot of tomato by Pseudomonas fluorescens and represses the production of pathogen metabolites inhibitory to bacterial antibiotic biosynthesis. Phytopathology 87:1250-2157.

7. Fenton, A. M., Stephens, P. M., Crowley, J., O'Callaghan, M., and O'Gara, F. 1992. Exploitation of gene(s) involved in 2,4-diacetylphloroglucinol biosynthesis to confer a new biocontrol capability to a Pseudomonas strain. Appl. Environ. Microbiol. 58:3873-3878.

8. Glick, B. R. 1995. The enhancement of plant growth by free-living bacteria. Can. J. Microbiol. 41:109-117.

9. Harrison, L. A., Letendre, L., Kovacevich, P., Pierson, E., and Weller, D. M. 1993. Purification of an antibiotic effective against Gaeumannomyces graminis var. tritici produced by biocontrol agent, Pseudomonas aureofaciens. Soil Biol. Biochem. 25:215-221.

10. Keel, C., Schnider, U., Maurhofer, M., Voisard, C., Laville, J., Burger, U., Wirthner, P., Haas, D., and Défago, G. 1992. Suppression of root diseases by Pseudomonas fluorescens CHA0: Importance of the bacterial secondary metabolite 2,4-diacetylphlorogluciol. Mol. Plant-Microbe Interact. 5:4-13.

11. Keel, C., Weller, D. M., Natsch, A., Défago, G., Cook, R. J., and Thomashow, L. S. 1996. Conservation of the 2,4-diacetylphloroglycinol biosynthesis locus among fluorescent Pseudomonas strains from diverse geographic locations. Appl. Environ. Microbiol. 62:552-563

12. Kirner, S., Hammer, P. E., Hill, D. S., Altmann, A., Fisher, I., Weislo, L. J., Lanahan, M., van Pée, K.-H., and Ligon, J. M. 1998. Functions encoded by pyrrolnitrin biosynthetic genes from Pseudomonas fluorescens. J. Bacteriol. 180:1939-1943.

13. Kloepper, J. W., Lifshitz, R., and Schroth, M. N. 1988. Pseudomonas inoculants to benefit plant protection. Pages 60-64 in: ISI Atlas of Science. Institute for Scientific Information, Philadelphia.

14. Louws, F. J., Rademaker, J. L.W., and de Bruijn, F. J. 1999. The three Ds of PCR-based genomic analysis of phytobacteria: Diversity, detection, and disease diagnosis. Annu. Rev. Phytopathol. 37:81-125.

15. Lugtenberg, B. J. J., de Weger, L. A., and Bennett, J. W. 1991. Microbial 
stimulation of plant growth and protection from disease. Curr. Opin. Biotechnol. 2:457-464.

16. McSpadden Gardener, B. B., Mavrodi, D. V., Thomashow, L. S., and Weller, D. M. 2001. A rapid polymerase chain reaction-based assay characterizing rhizosphere populations of 2,4-diacetylphloroglucinolproducing bacteria. Phytopathology 91:44-54.

17. McSpadden Gardener, B. B., Schroeder, K. L., Kalloger, S. E., Raaijmakers, J. M., Thomashow, L. S., and Weller, D. M. 2000. Genotypic and phenotypic diversity of phlD-containing Pseudomonas strains isolated from the rhizosphere of wheat. Appl. Environ. Microbiol. 66:1939-1946.

18. Nowak-Thompson, B., Chaney, N., Wing, J. S., Gould, S. J., and Loper, J. E. 1999. Characterization of the pyoluteorin biosynthetic gene cluster of Pseudomonas fluorescens Pf-5. J. Bacteriol. 181:2166-2174.

19. Nowak-Thompson, B., Gould, S. J., Kraus, J., and Loper, J. E. 1994. Production of the 2,4-diacetylphlorogluciol by the biocontrol agent Pseudomonas fluorescens Pf-5. Can. J. Microbiol. 40:1064-1066.

20. O'Sullivan, D. J., and O'Gara, F. 1992. Traits of fluorescent Pseudomonas spp. involved in suppression of plant root pathogens. Microbiol. Rev. 56:662-676.

21. Picard, C., Di Cello, F., Ventura, M., Fani, R., and Guckert, A. 2000. Frequency and biodiversity of 2,4-diacetylphloroglucinol-producing bacteria isolated from the maize rhizosphere at different stages of plant growth. Appl. Environ. Microbiol. 66:948-955.

22. Pierson, E. A., and Weller, D. M. 1994. Use of mixtures of fluorescent pseudomonads to suppress take-all and improve the growth of wheat. Phytopathology 84:940-947.

23. Pieterse, C. M. J., van Wees, S. C. M., Ton, J., Léon-Kloosterziel, K. M., van Pelt, J. A., Keurentjes, J. J. B., Knoester, M., and van Loon, L. C. 2000. Rhizobacteria-mediated induced systemic resistance (ISR) in Arabidopsis: Involvement of jasmonate and ethylene. Pages 291-296 in: Biology of Plant-Microbe Interactions. Vol. 2. P. J. G. M. de Wit., T. Bisseling, and W. J. Stiekema, eds. The American Phytopathological Society, St. Paul, MN.

24. Pooler, M. R., Ritchie, D. F., and Hartung, J. S. 1996. Genetic relationships among strains of Xanthomonas fragariae based on random amplified polymorphic DNA PCR, repetitive extragenic palindromic PCR, and enterobacterial repetitive intergenic consensus PCR data and generation of multiplexed PCR primers useful for the identification of this phytopathogen. Appl. Environ. Microbiol. 62:3121-3127.

25. Raaijmakers, J. M., Bonsall, R. F., and Weller, D. M. 1999. Effect of population density of Pseudomonas fluorescens on production 2,4-diacetylphlorogluciol in the rhizosphere of wheat. Phytopathology 89:470475.
26. Raaijmakers, J. M., and Weller, D. M. 1998. Natural plant protection by 2,4-diacetylphloroglucinol-producing Pseudomonas spp. in take-all decline soils. Mol. Plant-Microbe Interact. 11:144-152.

27. Raaijmakers, J. M., Weller, D. M., and Thomashow, L. S. 1997. Frequency of antibiotic-producing Pseudomonas spp. in natural environments. Appl. Environ. Microbiol. 63:881-887.

28. Rademaker, J. L. W., and de Bruijn, F. J. 1997. Characterization and classification of microbes by rep-PCR genomic fingerprinting and computer assisted pattern analysis. Pages 151-171 in: DNA Markers: Protocols, Applications, and Overviews. G. Caetano-Anolles and P. M. Gresshoff, eds. John Wiley \& Sons, New York.

29. Rademaker, J. L. W., Louws, F. J., Rossbach, U., and de Bruijn, F. J. 1999. Computer assisted pattern analysis of molecular fingerprints and data base construction. Pages 1-33 in: Molecular Microbial Ecology Manual. A. D. L. Akkermans, J. D. van Elsas, and F. J. de Bruijn, eds. Kluwer Academic Publishers, Dordrecht, the Netherlands.

30. Sambrook, J., Fritsch, E. F., and Maniatis, T. 1989. Molecular Cloning: A Laboratory Manual. 2nd ed. Cold Spring Harbor Laboratory, Cold Spring Harbor, NY.

31. Shanahan, P., O'Sullivan, D. J., Simpson, P., Glennon, J. D., and O'Gara, F. 1992. Isolation of 2,4-diacetylphlorogluciol from a fluorescent pseudomonad and investigation of physiological parameters influencing its production. Appl. Environ. Microbiol. 58:353-358.

32. Sharifi-Tehrani, A., Zala, M., Natsch, A., Moenne-Loccoz, Y., and Defago, G. 1998. Biocontrol of soil-borne fungal plant diseases by 2,4diacetylphloroglucinol-producing fluorescent pseudomonads with different restriction profiles of amplified 16S rDNA. Eur. J. Plant Pathol. 104:631-643.

33. Stutz, E., Défago, G., and Kern, H. 1986. Naturally occurring fluorescent pseudomonad involved in suppression of black root rot of tobacco. Phytopathology 76:181-185.

34. Tamietti, G., Ferraris, L., Matta, A., and Abbattista Gentile, I. 1993. Physiological responses of tomato plants grown in Fusarium suppressive soil. J. Phytopathol. 138:66-76.

35. Thomashow, L. S., and Weller, D. M. 1996. Current concepts in the use of introduced bacteria for biological disease control: Mechanisms and antifungal metabolites. Pages 187-235 in: Plant-Microbe Interactions. Vol. 1. G. Stacey and N. Keen, eds. Chapman and Hall, New York.

36. Van Loon, L. C., Bakker, P. A. H. M., and Pieterse, C. M. J. 1998. Systemic resistance induced by rhizosphere bacteria. Annu. Rev. Phytopathol. 36:453-483.

37. Weller, D. M. 1988. Biological control of soilborne plant pathogens in the rhizosphere with bacteria. Annu. Rev. Phytopathol. 26:379-407.

\section{Erratum}

\section{Vol. 91, No. 1, 2001}

In the manuscript entitled "Genetic Diversity of phlD from 2,4Diacetylphloroglucinol-Producing Fluorescent Pseudomonas spp." by O. V. Mavrodi, B. B. McSpadden Gardener, D. V. Mavrodi, R. F. Bonsall, D. M. Weller, and L. S. Thomashow (Phytopathology 91:35-43), Figures 1 and 2 are transposed. The correct image of the random amplified polymorphic DNA (RAPD) cluster analysis and fingerprint patterns generated from genomic DNA of phlD-containing Pseudomonas spp. strains is shown in Figure 2. An illustration of the cluster analysis of restriction fragment length polymorphism (RFLP) patterns obtained by digestion of a 745-bp phlD fragment is shown in Figure 1. 